Ivo Pospíšil

Masarykova univerzita Filozofická fakulta Ústav slavistiky Brno, Česká republika Ivo.Pospisil@phil.muni.cz
УДК 314.151.3-054.7:94(437)(=161.1)"193"

https://doi.org/10.18485/slavistika.2021.25.1.4

Оригинални научни рад примљено 03.05.2021.

прихваћено за штампу 17.06.2021.

\title{
VALERIJ VILINSKIJ A SLOVANSKÁ OTÁZKA, JEJÍ KONTEXT A KRIZE 30. LET 20. STOLETÍ*
}

Př́ítomná studie pojednává o jedné z publikací ruského emigrantu, právníka, politologa a novináře Valerije Vilinského (1903-1955), syna smluvního profesora Masarykovy univerzity Sergije Vilinského (1876-1950), který sehrál důležitou rolii v politickém vývoji Československa po roce 1945, člověka tragického osudu. Tématem je jeho drobná práce $K$ slovanské otázce. Tř́ koncepce slovanské vzájemnosti (1930). Valerij Vilinskij, jehož některými jinými publikacemi se autor př́tomného pojednání zabýval, zde vykládá tři koncepce tzv. slovanské vzájemnosti, demokratickou, katolickou a rusofilskou. V tomto prríspěvku se práce Vilinského kriticky posuzuje a interpretuje se prolínání uvedených tř́ koncepcí v souvislosti s jinými jevy meziválečného Československa, kde Vilinskij žil, na pozadí všeobecné krize 30. let 20. století a v konfrontaci s odbornou literaturou.

Klíčová slova: Valerij Vilinskij, slovanská otázka a tři koncepce slovanské vzájemnosti, souvislosti Vilinského koncepce na pozadí všeobecné krize 30. let 20. století.

The present study discusses one of the publications of the Russian émigré, lawyer, political scientist and journalist Valerii Vilinskii (1903-1955), son of the contractual professor of Masaryk University Sergii Vilinskii (1876-1950) who played a significant role in Czechoslovakia's political development after 1945, a man of a tragic fate. The subject-matter is represented by his minor work On the Slavonic Question. Three Conceptions of Slavonic Mutuality (1930). Valerii Vilinskii, whose other publications the author of the present treatise dealt with, explains the three conceptions of the so-called Slavonic mutuality, i. e. democratic, Catholic, and Russophile. In this contribution Vilinskii's work is critically examined, and the permeation of the three mentioned conceptions is interpreted in connection with other phenomena of interwar Czechoslovakia where Vilinskii lived, against the background of the general crisis of the 1930s and in comparison with specialist literature.

Keywords: Valerii Vilinskii, Slavonic questions and three conceptions of Slavonic mutuality, the contexts of Vilinskii' conception against the backdrop of the general crisis of the 1930s.

Zvěčnělý kolega prof. Miodrag Sibinović hluboce zasáhl do srovnávací filologie, zvláště do literární vědy ve smyslu mezislovanských literárních vztahů a slovanské meziliterárnosti, zvláště srbsko-ruské, ale také do teorie překladu, translatologie i do překladatelské praxe; byl filologem v širokém slova smyslu. Slovanská otázka nemohla tudíž nestát v pozadí jeho studií a knih: její různé traktování a nasvěcování znamenalo také pohyb filologické a areálové slavistiky po dlouhá desetiletí. I když by se zdálo, že slovanská otázka dnes, v době zatlačování národního programu a minimalizace role národních států v globalizovaném světě, kdy historicky vzniknuvší

* Tento výstup vznikl na Masarykově univerzitě v rámci projektu Mezislovanské kulturní a literární vazby číslo MUNI/A/1331/2020 podpořeného z prostředkủ účelové podpory na specifický vysokoškolský výzkum, kterou poskytlo MŠMT v roce 2021. 
nebo staletí pocit’ované celky ztrácejí na významu, již není nijak aktuální, nelze ji zcela ignorovat nebo dokonce negovat; má nejen diachronní význam pro poznání slovanské minulosti, ale zasahuje také do současnosti a odpovědi na ni se vážou na reálný výklad literatury (Pospíšil 2016).

Sergij a Valerij Vilinští, otec a syn, jsou spjati s univerzitou, na níž působím více než 45 let. Jde zejména o otce, který ve 20. letech 20. století získal na nově založené druhé české (Masarykově) univerzitě místo tzv. smluvního profesora: měl profesorské povinnosti, ale nebyl jmenován prezidentem Československé republiky, jenž, jak známo, přijímal nově jmenované rédné (ordinarius) univerzitní profesory v osobní audienci (aby zdůraznil jejich prominentní společenský a politický význam a úctu a vážnost, které se tato hodnost tehdy ve společnosti a ve státě těšila), a měl i podstatně nižší plat. Ordinariem se stal až po roce 1945, kdy byly znovu otevřeny české vysoké školy (na Slovensku tzv. Slovenská univerzita, předtím Univerzita Komenského, přejmenovaná roku 1939 po vzniku loutkového Slovenského štátu za rektorování Vojtecha Tuky v letech 1939-1942, popraveného roku 1946) uzavřené v Protektorátu Böhmen und Mähren roku 1939 německými nacistickými úřady. Mezi ruskými porevolučními emigranty, kteří působili na území meziválečného Československa, později Protektorátu Čechy a Morava a Slovenské republiky (od 14. 3. a 15. 3. 1939), byl i jeho syn Valerij. Jde o príběh otce a syna, kteří profesně zakotvili v Brně a Praze, ale oba úzce spolupracovali i se Slovenskem. Bylo to logické: Praha a Brno je lákaly, nebot' to byla tehdy vzdělanostní a vědecká centra, navíc v Praze a celých Čechách a na Moravě žila řada ruských emigrantů podporovaných v rámci Ruské podpůrné akce, ale Slovensko jim oběma bylo ideově bližší, nebot' zde našli pevné náboženské zázemí: oba byli sice pravoslavní, ale lákal je zejména katolicismus a Valerij byl velkým propagátorem ekumenismu. Zatímco Sergij Vilinskij získaný profesory Stanislavem Součkem (18701935) a Václavem Vondrákem (1859-1925) pro Masarykovu univerzitu jako smluvní profesor zůstal částí své činnosti sice ukotven v medievistice, kterou pěstoval na Novorossijské univerzitě v Oděse, ale přece jen se musel odborně přeorientovat na modernější literaturu (M. J. Saltykov-Ščedrin, Petko Todorov) a snažil se sporadicky spolupracovat i s katolickými kruhy na Moravě, jeho syn Valerij pronikl do českého prostoru mnohem razantněji. Oběma jsem věnoval řadu studií publikovaných v různých periodikách a sbornících, speciálně jsem si u Valerije Vilinského všiml jeho knihy o Československu, kde jasnozriivě uviděl perspektivy takového státu, jakož i podmínky jeho rozvoje, ale ovšem i jeho slabiny, jež se ukázaly jako osudové (Pospíšil 1996a, 1996b, 2000a, 2015a, 2017a, 2017b; Поспишил 2012a, 2015b).

Fixními idejemi Valerije Vilinského, jehož život se nakonec vyvíjel tragicky až $\mathrm{k}$ jeho údajné sebevraždě, byla křest’anská unie, tedy spojení křest’anských církví, v němž si kromě pravoslaví vážil univerzálního katolicismu, zatímco méně mu konvenují protestantské církve, a idea nového Ruska spjatého s tzv. ruskou revolucí jako dlouhodobým procesem a také slovanská otázka, kterou zkoumal na př́kladu jejího oživení ve 20. století také v souvislosti se vznikem nových slovanských státủ (Československo, Polsko, Jugoslávie) a nového Ruska, které se sice rozvíjí jinou cestou, než by si přál, ale byla zde naděje na výraznou vnitřní i vnější změnu. Ideový kvas v ruské emigraci, např. v reakci na novoslovanství a euroasijství (евразийство) vedl i k vývoji nových představ, jež neustrnuly na starých koncepcích spojených s předrevolučním Ruskem, ale uviděly Rusko jako dynamický celek v kontextu roz- 
víjející se Evropy, která se na přelomu 20. a 30. let 20. století dostávala do nové krize hospodářské i politické a jež vyústila v novou válku. Kromě diachronně synchronních pohledů na ruskou revoluci chápanou jako dlouhodobý proces trvající tehdy minimálně více než jedno století a vytváření křest’anské církevní unie se slovanská otázka stávala znovu v nových pozicích a souřadnicích aktuální (Vilinskij 1930).

Valerij Vilinskij vidí hlavní změnu v této otázce po roce 1918 v tom, že se stala záležitostí státní na rozdíl od situace před první světovou válkou, kdy se státní aspekt týkal jen těch Slovanů, kteří měli samostatné státy (Rusko, Srbsko, Bulharsko). Zásadní je potom vyřazení Ruska z tohoto okruhu, nebot', jak říká, Rusko neprojevuje slovanskou politiku a k slovanským státům se chová jako k jiným. Hlavním problémem sblížení Slovanů a vytváření toho, čemu se někdy říká slovanský svět, je vyřešení vzájemných mezislovanských sporů. Nepř́iliš přesvědčivě se domnívá, že byl vyřešen problém československý, jihoslovanský a polský, ale objevil se problém polsko-ruský a jihoslovansko/jugoslávsko-bulharský. Tam vidí zásadní otázku makedonskou a u Bulharů k tomu ještě egejskou (tedy bulharsko-řeckou) a dobrudžskou (tedy bulharsko-rumunskou). V podstatě přesně uviděl problém ukrajinský, který je podle něho zaměřen proti Rusku i proti Polsku. Nevyjasněna zůstává pozice Slovanů na území neslovanských států: Slovinců a dílem i Srbů a Chorvatů v Rakousku a Itálii, Slovanů v egejské Makedonii a Thrákii, tedy podle identity Bulharů, Makedonců. Albánský problém nebyl tehdy dominantní tak, jak je tomu dnes, a ani otázka náboženská nenabývala tak ostrých konfliktních poloh.

Valerij Vilinskij si povšiml francouzských komentářu k významu slovanského světa ve střední Evropě a na Balkáně, kde se vytvořily velké státy: tehdy čtrnáctimilionové Československo s Podkarpatskou Rusí, Třicetimilionové Polsko a na jihu pak Jugoslávie a Bulharsko. Francouzský komentátor se domníval - ne zcela správně, že by tyto země byly připraveny od Baltu k Jadranu hájit územní celistvost do posledního dechu (Vilinskij 1930: 16). Vyvedením Ruska po Ř́jnové revoluci z okruhu dominantního faktoru mezislovanské vzájemnosti se posilují vztahy nově vzniklých slovanských států se Západem. Nicméně: ,,Jakákoli by byla budoucnost Ruska, utužení styků Slovanstva se Západem vůbec neznamená, že by tyto nové státy svou spoluúčastí v evropském konsolidačním procesu pomáhaly vytvoření hráze, namířené proti Rusku; jejich činnost musí být právě vykládána jako prrípravná práce $\mathrm{k}$ tomu, aby Rusku po letech dobrovolné izolovanosti bylo umožněno připojiti se k evropskému vývoji. Okolnosti, že Rusko nejeví zájmu o slovanskou součinnost, nemůže zadávati podnět k tomu, aby poměr ostatních Slovanů k Evropě zůstával ve stavu ,pendente conditione ${ }^{e}$. Tato taktika byla velice krátkozrakou a ve svých důsledcích téměř protiruskou, poněvadž by znamenala politiku ztracených možností, a to takových, jež mají nemalý význam i pro samotné Rusko“ (Vilinskij 1930: 16-17).

Celá koncepce knihy vychází z řady studií, které Valerij Vilinskij psal pro různé časopisy, především, jak uvádí, pro polský Przegląd powszechny, pařížský ruský emigrantský časopis Vozroždenije a pražský Volja Rossii. Takto je ostatně celá koncepce respektována: primárně na problém polsko-ruský a na českou recepci a obecné pojetí slovanské otázky.

Klíčová je v knize o slovanské otázce druhá kapitola, která srovnávacím způsobem zkoumá reálnou základnu slovanské vzájemnosti v pojetí různých slovanských národů a jejich ideologické a politické reprezentace. Začíná dobovými bulharský- 
mi projevy, jež byly nemnohé, ale objevuje se v nich představa slovanské federace. Cituje několik článků a dochází $\mathrm{k}$ závěru, že by se tyto představy o ruské dominanci, ovšem s Ruskem jiným než bolševickým, hodily spíše do arzenálu básníka, tedy že jsou hodně emotivní, nikoli reálné, když připustíme spory rusko-polské a srbsko-chorvatské. Vyzdvižení Jugoslávie a obnoveného Polska by působilo výrazněji, kdyby na mezinárodních dohodách participovalo Rusko. Vládnoucí směry jihoslovanské odkazují k jakési slovanské jednotě, kde Rusko neztratí svou důležitou nebo dokonce vedoucí úlohu, ale Rusko jiné než současné. Třetí směr - katolický - představují někteří Slovinci a Chorvati, kteří při uznání přátelského vztahu s Ruskem jsou spíše západní orientace. Na základě analýzy dobové časopisecké produkce ukazuje na územní nároky Ruska vůči novému Polsku, ale myslí tím nové postbolševické Rusko, byt' stávající hranice byly mezinárodně dohodnuty. Polská stanoviska vůči Rusku byla rozporná: jedni si přáli rozdělení Ruska a vznik velké Ukrajiny, jiní to naopak odmítali: zajímavé je, že tyto koncepce, byt' podprahově, nikoli nahlas, v polských stanoviscích k rusko-ukrajinské otázce se občas vyskytují. Zvláštní pozornost věnuje Valerij Vilinskij českým názorům, z nichž vyzvedává zejména tzv. demokratický, v podstatě Masarykův a Benešův, a po něm Kramářův novoslovanský; sám to vidí tak, že slovanská politika je součástí a prostředkem demokratické a všelidské politiky (Vilinskij 1960: 39). Jde o koncepci, kterou u nás nahlas vyslovil už Karel Havlíček Borovský: není rozdílu mezi Slovanem a člověkem, rovnoprávnost národů velkých a malých, neuznávání prvenství, protektorství nebo mesianistické poslání jakéhokoli národa. Odmítá také rusofilství a panrusismus; slovanství není proti žádnému národu, tedy ani německému. Sjednocování slovanské je podle této koncepce stupněm k demokratické organizaci světové.

Na okraj poznamenávám, že podobné stanovisko vyslovili ve 20. století ve stopách Masarykových, ale pokud jde o analýzu materiálově podloženěji, např́klad Frank Wollman, jeho syn Slavomír Wollman a jiní (F. Wollman 1928, 1936, 1937, 1958, 1968, 2003, 2012; S. Wollman 1988, 1989, 2013; Pospíśil 1998, 2005, 2014, 2016), i když např. F. Wollman byl důraznější v hledání společných slovanských topoi/loci communes, tzv. slavismů, ale nepomíjí ani tzv. antislavismy (Wollman 1968). Oproti Masarykovu směru, jak již bylo uvedeno, stál směr Kramářův, v podstatě silně emotivní a hlavně geopolitický, mocenský, tedy mezinárodní prosazení slovanské síly teritoriální a populační jako hráz vytváření impérií, zejména německé. Rusko je v této koncepci protektorem, i když se to prŕmo neř́ká. Pokud jde o ruskou, potažmo sovětskou politiku, která, jak většina badatelů tvrdí, není slovanská a Slované tu v té době (meziválečné) nezaujímají důležité místo. Ukazuje se, že nový sovětský režim některé klíčové otázky carského Ruska odsunul stranou, vyzvedl např. kdysi celkem slabý problém ukrajinský, ale v budoucnu, jak se tu tvrdí, jistě i otázka Cařihradu a úžin nabude znovu na významu. Rusové sami se musí vyrovnat s koncepcemi 19. století, kdy šlo v podstatě o dominanci Ruska v slovanském světě, ale také strach vyjádřený kdysi Dostojevským, totiž že osvobození Slovanů bude pro Rusko největší hrozbou. Když se na tyto shrnující poznámky Valerije Vilinského podívám z časového odstupu v podstatě takřka devadesáti let, musím uznat, že téměř všechny názory a předpoklady někdy znovu vstoupily do hry a dokonce vícekrát: to je věčný problém, rusko-polský, resp. rusko-polsko-ukrajinský, nebot' je to zjevný trojúhelník, kdy všechny tři země mají své zájmy, jež jsou v rozporu se zájmy dvou zbývajících, včetně pohledu 
na historii, který je i dnes nesmiřitelný; k tomu dne přistupuje složitěji utvářený vztah česko-ruský, podstatně se lišící od vztahu slovensko-ruského. Totéž se týká problému Cařihradu, i když dnes nabývá spíše podoby široce koncipovaného rusko-tureckého vztahu oscilujícímu mezi vynuceným spojenectvím a zjevným nepřátelstvím, a tedy již tak zřetelně - zejména z hlediska náboženského - nevystupuje do popředí a je řešen jiným zpo̊sobem, ale tvrdím, že je svým způsobem stále přítomen. Podobně problém Balkánu slovanského i neslovanského, posílení zájmů dnešního Turecka, rozpad Jugoslávie a válka v 90. letech 20. století - a tento konflikt podprahově pokračuje - svědčí o tom, že v průběhu 19. a první poloviny 20. století byly k slovanské otázce vysloveny $\mathrm{v}$ podstatě všechny důležité názory a uvedeny všechny možné relevantní koncepce, a to u různých národů. Do ruského pohledu na slovanskou otázku vstupují často názory slovanských umělců, např́iklad je zde uveden básník Konstantin Balmont, mimochodem milovník českých zemí (Бальмонт 1931; Balmont 2001), který nejednou vyjadřoval lítost nad mezislovanskými nesváry.

Klíčem k pochopení Vilinského pozice je kapitola třetí, v níž jde o aplikaci různých pojetí. Na prvním místě jmenuje dvojí pojímání slovanské politiky: tzv. revoluční a státotvorné. Revoluční bylo zdrojem permanentního neklidu, a právě toho se obávaly jiné země: šlo primárně o boj o kulturní a také politickou autonomii Slovanů ve větším státním celku s vyústěním ve vytvoření vlastního národního státu. Rusko, které bylo samostatné, a tedy aplikovalo spíše státotvornou formu, muselo na sebe brát i roli ochránce Slovanů, která mu v podstatě byla ostatními Slovany vnucena, na počátku 19. století se to zdánlivě překvapivě týkalo také Poláků (viz naši studii o panslavismu). Po vzniku velkých slovanských států po roce 1918 se podle V. Vilinského předním úkolem stala transformace revolučního pojetí do státotvorného, současně však také o uchování revolučního potenciálu, jenž by však nebyl hrozbou pro jiné národy a státy, naopak posiloval potencialitu vzájemné kooperace a spojování různých národů v jednom státě: to byl problém všech nových slovanských států, Polska, ale hlavně Československa a Jugoslávie. Pokud jde o vnitřní pojetí, uvádí směr demokratický (Masarykův apod.), katolický a rusofilský; v dalším textu tyto směry označuje i jinými, podobnými termíny.

Rusofilský nazývá někdy „tradiční“ a myslí tím jednoznačnou vazbu na Rusko, která byla i v českém prostředí typická minimálně pro první polovinu 19. století, ale i o něco později. To také souvisí s realizací tehdejších geopolitických projektů, v nichž se již nebylo možné opírat o jakési Velké Rusko, např. Malé dohody (Petite Entente). Potřeba vytvářet velký středoevropský geopolitický celek vznikl přirozeně jako nezbytí nahradit rozpadlé Rakousko-Uhersko, ale nikdy se ho nepodařilo plně realizovat. Jako doplnění uvádíme meziválečnou snahu o oživení konceptu Střední Evropy, oproštěného od velkoněmecké ideologie vyjádřené v knize Friedrich Naumanna Das Mitteleuropa (1915), tedy volnou, především hospodářskou spolupráci a obnovu ekonomického, obchodního, finančního a dopravního a koneckonců i nejpevnějšího kulturního celku mezi Rakouskem, Mad’arskem, Československem, dále i Itálií a Jugoslávií, jehož tvưrcem byl mj. mad'arský vědec Elemir Hantos (Pospíšil 2004, 2006a, 2006b, 2015a; Jeřábek 2008; Litteraria Humanitas XI 2002; Comparative Cultural Studies in Central Europe. 2004; Hantos 1925a, 1925b, 1926, 1928, 1929, 1931a, 1931b, 1932a, 1932b). Centrem tohoto úsilí bylo Brno a Právnická fakulta Masarykovy univerzity se svou vědeckou školou normativního, novokantovského práva Františka Weyra, kde se 
ve 20. s 30. letech minulého století konaly různé konference a setkání, na nichž se o těchto věcech hovořilo; tato fakta však Vilinskij neuvádí.

Dnes je tu Visegrádská čtyřka a různé peripetie její existence a působení a také různá míra její spolupráce a rozporů: dř́ve se myslelo, že by to mohl být přechod těchto „postkoloniálních“ zemí do EU, později se zase utvářela jakási opozice vůči některým politickým tendencím ve vedení $\mathrm{EU}$, hlavně zde reálně vládnoucích zemí, tedy Německa a Francie, nikdy však jako celek nefungovala: jak Malá dohoda, tak Visegrádská čtyřka, v níž je však ještě mnohé otevřeno. Nakonec se ukázala nosnou orientací prrímo na Západ, dokonce na euroatlantickou vazbu, jak to ukázalo k Visegrádu v posledních letech, patrně z ekonomických důvodů, inklinující malé Slovinsko, byt' se členem čtyřky nakonec nestalo, hned po osamostatnění z rámce Jugoslávie a jeho zvláštní vztahy k USA: tyto sbližovací a vzdalovací pohyby se projevily zvláště silně od počátku 21. století a probíhají v oslabené formě dodnes. Jde, jak patrno, o jakési kopírování pozice bývalého Rakouska-Uherska, jež tu zjevně chybí, i když př́činami jeho zániku byly zase vnitřní, antagonistické rozpory, jejichž překonávání se řešilo tak, že některé zájmy musely ustoupit a nerealizovaly se (někdejší slovansko-německo-mad’arský konflikt s různými akcenty a výsledky). Zdá se tedy, že pro západoslovanské národy je takové sbližování hospodářské a dílem i politické spíše záležitostí pragmatickou a lze se o ně opírat, jako by se tu dědily staré rozpory monarchie, jen převedené do jiných státních celků, kde však chybí potenciální scelující role dědičného trůnu. Neoslovanství, silné ke konci 19. století (Karel Kramář), ve 20. století ustupuje zejména pod tlakem narůstajících mezislovanských sporů, Rusy využívané neochoty rakousko-uherských úřadů řešit slovanskou otázku a také zvětšujících se rozdílů mezi převážně západní a převážně východní částí ríše (Předlivskem/Cisleithanien a Zalitavskem/Transleithanien).

Katolický směr si Valerij Vilinskij ponechává nakonec a vidí v něm hlavní naději, jak v slovanské otázce postoupit kupředu a učinit ji integrativní složkou evropskou a světovou. Je tu především katolický universalismus, tolik obdivovaný zejména pravoslavnými Rusy (Gogol, ruští jezuité ve Francii, např. slavný katolický kněz, kníže Ivan Sergejevič Gagarin, 1814-1882). Vilinskij správně postřehl také to, že Rusko rozkročené mezi Evropou a Asii a mající také integrující asijské základy dané několikasetletou mongolsko-tatarskou okupací, ale také vzájemným soužitím a ovlivňováním, má ještě jiné geopolitické zájmy, které je vzdalují problémům slovanským, tedy evropským.

Čtvrtá kapitola pojednává o řadě dalších aspektů, jež vyvstaly zejména ve 20. století v důsledku první světové a občanské války v Rusku a samozřejmě vzniku velkých slovanských států. Vilinskij analyzuje dobové sbližování polsko-ruské v otázce ukrajinské, ale to, jak víme, bylo oslabeno posílením SSSR po roce 1939 a zejména 1945, a naopak od 90. let 20. století se vyvinulo ve sbližování polsko-ukrajinské, byt' hodně čerchované. Zde možná Vilinskij nedoceňuje fakt, že Rusko od reforem Petra I. mířilo vždy na nejzazší Západ, tedy k sbližování s vlivy francouzskými a britskými, ale i dalšími, přičemž se opomíjel právě kulturní areál střední Evropy a Balkánu budovaný Slovany i jinými národy, kde si chtělo Rusko udržet vliv, a stát tak hodnotově jakoby nad nimi právě v zápase se západními mocnostmi, Francií a Velkou Británií, a také Německem, které se rozprostřelo od Západu na Východ (linie Západ - Východ vedla tradičně po ose Kiel - Terst), zvláště po sjednocení po vítězné válce Pruska s Francií. 
Tak se například stalo, že ruský romantismus vzniká přibližně ve stejné době jako anglický a skotský, jen pár roků po německé univerzitní, tzv. rané romantice či romantismu (die deutsche Frühromantik; viz Horyna 2005), zatímco u západních Slovanů je vše opožděno, a to i v jinak literárně nesmírně rozvinutém Polsku, nejen u nás a na slovanském jihu, nemluvě o tom, že se některé směry, včetně romantismu zužují nebo jsou v podstatě neexistentní (např. český romantismus je zpočátku spíše sentimentalismem nebo preromantismem, snad s výjimkou K. H. Máchy; i tzv. realismus Boženy Němcové je vlastně zastydlým sentimentalismem, stejně jako do značné míry tvorba J. K. Tyla, jak to správně uviděl již K. Havlíček Borovský). Zde Vilinskij vyslovuje názor, jenž je zjevně podpořen dobovými náběhy, které však později „,vychladly“, např. to, že Polsko táhne Rusko na Západ (to mohlo platit v 17. a jen do jisté míry v 18. století, kdy bylo nahrazeno prrímým přesahem $\mathrm{k}$ Západu, a to spíše jen ve sfére kultury a umění, např. baroko, klasicismus apod., deroucí se z Polska do Ruska přes tzv. západní Rus, tedy dnešní Bělorusko a Ukrajinu, viz Lappo-Danilevskij 2005; Pospíšil 2006c: 326-327): jde vždy o to, jak se k tomu staví právě ten prostor, k němuž má být jiný prostor přitažen, nejde tedy primárně o mediátora.

Kniha V. Vilinského, byt' má spíše ráz politologicko-žurnalistický, se v řadě míst rozevírá do hloubky diachronně: to jsou všechna místa, v nichž pojednává o kontroverzích, včetně tragických sporů jihoslovanských, polsko-ruského, ale i jiných. Vilinskij nepomíjí ani zájem Ruska nejen o Balkán a střední Evropu, ale také o oblast Baltie/Pobaltí, tedy to, čeho si Vilinskij všiml a co kopíruje území Ruského impéria. Tu se mohou, byt' dočasně, sblížit zájmy Ruska a baltských národů, nebo naopak Ruska a Polska. Vilinskij nevidí problém běloruský, i když i zde se, jak známo, zájmy Ruska jasně projevily, ale spíše problém ukrajinský, jak se ukazuje i dnes. Nicméně za klíčový pokládá vztah rusko-polský, a - jako polonofil - vidí v rusko-polském sbližování a postupném (jde však o běh na dlouhou trat') překonávání rozporné minulosti, což se nakonec ukázalo ještě složitější, než se tehdy zdálo, dokonce i geopoliticky (postoj Poláků k tzv. západním územím a na druhé straně ke kresům, k Haliči, tzv. západní Ukrajině a Bělorusi).

Vilinskij tu také spekuluje o sbližování Polska s Malou dohodou, což se také ukázalo jako utopické, byt' zde Polsko působilo spíše jako disperzní prvek, např́iklad zvláštními vztahy k Mad'arsku/Uhersku a Rumunsku. Dál už neuvažuje, ale jistě by tu byly - i vzhledem k současnosti - důležité zájmy směrující na Blízký a Střední Východ, k Persii/Íránu a Indii, o čemž svědčí i ruské vojenské a politické tahy od časů Kateřiny II. a Pavla I., ale také sovětské diplomatické iniciativy směrem k Indii a Pákistánu v 60. letech 20. století, nyní intervence (hájení ruských zájmů jako výrazu vlastního ohrožení tak, jak to dělají i jiné velmoci, často extrémně daleko od vlastního území) v Sýrii apod.

Správně Vilinskij předpokládá, že v dohledné době nebude mít Rusko slovanské ambice ve smyslu využívání tzv. slovanské otázky. Ukázalo se, že i tehdy, kdy to bylo výhodné, udržovala se „slovanská“ orientace SSSR, resp. hraní slovanskou kartou, jen čistě pragmaticky a na velmi krátkou dobu (koketérie se „slovanskou politikou“ po roce 1945, některé sovětské práce chápající Velkou/první světovou a druhou světovou válku jako odvěký boj Slovanstva s Germánstvem apod.). Aniž by význam rusofilského směru snižoval nebo jej zcela eliminoval, myslí si Vilinskij celkem správně, že je nutné toto stanovisko revidovat. 
Rusofilské hledisko nakonec srovnává s tzv. demokratickým takto: „Mezi demokratickým pojímáním slovanství a rusofilskou doktrínou je velice mnoho rozdílů; nejnápadnějšími a nejvíce patrnými jsou programové rozdíly čistě praktického rázu. Avšak politická praxe není nejdůležitějším bodem, který by opravňoval k hodnocení obou koncepcí jako zcela protichůdných. Největším a skutečně podstatným rozdílem zůstává okolnost, že demokratické slovanství navazuje na určitý světový názor, kdežto rusofilská koncepce nemá této odtažité základny, a chápe proto slovanskou vzájemnost jen z hlediska citového, přechodné politické konstelace, etnických a třídních zájmů a tak dále." (Vilinskij 1930: 94).

Zde nutno ještě před kulminací výkladu Vilinského, která směřuje k syntéze katolického a demokratického proudu, nutno předznamenat, že rusofilský směr není pouze emotivní, citový, jak uvedeno, ale že má i reálný, racionální základ. Ruské zájmy nejsou identické se zájmy jiných, „menších“ Slovanů, stejně jako zájmy neslovanských národních států nejsou totožné se zájmy Slovanů ne proto, že jde o jiná etnika, což vlastně není často ani pravda (např. Češi mají podle genetických zjištění silný prvek germánský; někteří tvrdí, že i keltský, což asi není přesné, ovšem kromě jiných, a kromě většinového slovanského). Jinak řečeno: „hlas krve“ tu nemůže být směrodatný, podstatnější by mohl být důvod ideologický a prakticky politický, ale nejpevnějším tmelem národní identity, tedy i národních států, je jazyk a vše s ním spojené, hlavně jeho produkty; ani onen demokratický názor, který spojuje různé národní státy, jistě i slovanské nemůže být stabilním východiskem, nebot' realizace obecné demokracie se v jednotlivých zemích podstatně liší, a i když najdeme styčné body, je tu také mnoho rozdílů daných obecně i kulturně historicky, ale jistě i empiricky. Ostatně stav střední Evropy ve 30. letech minulého století, kdy právě Československo bylo jedinou relativně fungující demokracií (byla tu ovšem ústavu prakticky přesahující role Hradu, tedy autorita Prezidenta Osvoboditele, který do politiky silně, byt' většinou nepřímo, zasahoval) obklopenou přinejmenším autoritativními režimy. Za obecnou ideologií, stejně jako emocí, jsou často zcela střízlivé zájmy ekonomické a úzce skupinové až osobní, jinak by asi nebyly války vůbec nebo alespoň ne tak časté a vleklé. Ani tu bych - na rozdíl od Valerije Vilinského - neideologizoval ten nebo onen směr, spíše bych hledal skryté motivace a reálné fungování.

Vilinského koncepční konstrukce nacházíme v páté kapitole. Jistě tu nemohl pominout integrační potenciál cyrilometodějské mise a jejího kulturního významu spojujícího Západ a Východ. K cyrilometodějské tradici právě ve 20. století inklinuje - po známém konfliktu nové republiky s Vatikánem, zvláště od svatováclavského milénia 1929, unionistická koncepce českých katolíků v tzv. Apoštolátu sv. Cyrila a Metoděje, světové organizace se sídlem v Olomouci ve spojitosti s cyrilometodějskou encyklikou Lva XIII. Grande munus (1880) a ve 20. století s činností olomouckého arcibiskupa Antonína Cyrila Stojana spojenou s poutěmi na Velehrad. Vilinskij vychází z tehdy aktuálních ,námluv“ demokratického a katolického proudu, směřujících k vzájemnému respektu ve smyslu společné státní politiky: katolíci, dříve radikální zastánci rakousko-uherského klerikalismu, by se měli stát a stávali se oporou československé státní ideje, aniž by popírali zájmy Vatikánu jako duchovního, ale také politického a státního centra katolíků.

Katolický univerzalismus by mohl být také silným faktorem náboženského univerzalismu, jenž by posiloval a sjednocoval slovanský svět jako takový. Vilinského 
idée fixeje křest’anská unie, ale slovanská otázka překračuje náboženský svět a míří k sekularismu, v dnešní době k postsekularismu (Pospíšil 2018), i když křest’anská unie nepochybně směřuje k popularizaci a silnějšímu vlivu slovanské otázky; jde o dvě roviny, které se protínají na značně úzké ploše. Zásadní rozdíl nespočívá ani v boji demokracie s teokracií, jak o tom psal Masaryk, ale spíše v jiném pojetí národa a národního státu jako nositele víry: unionistický směr v katolicismu nemůže přijmout sekularizaci nebo nacionalizaci náboženských kultů, včetně Cyrila a Metoděje, jde mu o vnitřní, nikoli jen emotivní hodnotu národa. Zde je katolický unionismus bližší „demokratickému“ nazírání na slovanskou otázku než směr rusofilský, zvláště pokud je nevýbojný, jak Vilinskij předpokládá, spojující Východ a Západ. Vilinskij končí jasně optimisticky: „Katolíci, přes celou odlišnost svého pojetí slovanství, musí přece uznati, že stojí vlastně v jednom táboře se stoupenci demokratické koncepce; obojí se přidržují doktrín, jež jsou odvozovány od určitých světových názorů, kdežto rusofilism spočívá na zcela odlišných předpokladech. Ačkoliv tyto světové názory jsou různého obsahu, přece formálně, alespoň podle své struktury, jsou stejně hodnotné, kterážto okolnost poskytuje možnost nejenom boje, nýbrž také úcty k odpůrci. Pokud obě koncepce se stýkají při společné práci v oboru slovanské státní politiky, mohou se navzájem respektovat a neprričiňovati se o to, aby stát byl jednostranně zneužíván za účelem omezení kulturního zápolení. Při splnění této podmínky se strana demokratického slovanství, uznání kladných hodnot unionismu, alespoň potud, pokud přináší nepopiratelný, tř̌ebas nepř́mý užitek státu, může být jejich oboustranný poměr zcela loyálním. A tak obě pojímání - katolické i demokratické - při stálém duchovním zápase o uplatnění a obsah určitých hodnot, mohou svorně spolupůsobiti ve prospěch státní slovanské politiky a býti jejími stejně důležitými pilíri v nejhlubších národních vrstvách.“(Vilinskij 1930: 118).

Při kladném ocenění těchto úvah a syntetického úsilí, nelze Vilinského pohled jednoznačně přijmout jako odpovídající dobové historické realitě. Je to dáno především tím, že jde o svár nadnárodní a národní ideologie, pokud Slovany pokládáme za nějaký relativně homogenní celek. A v tom je právě kámen úrazu: jestli existují Slované jako takoví, jestli existuje Slovanstvo, jestli existuje tento nadnárodní fenomén jako hodnotový průsečík a jak je stabilní nehledě na historické proměny. Nelze se zabývat slovanskou otázkou, aniž bychom definovali podstatu Slovanů, Slovanstva. Zde se nám vrací známý spor nominalistů s realisty. Tedy zda existují Slované nebo jsou jednotlivé slovanské národy, které vykazují určité společné rysy, jež pak nazýváme slovanskými nebo slavismy. Ještě ve 20. letech 19. století uvádí Pavel Josef Safařík (1795-1861), druhdy ředitel gymnázia v Novém Sadu (Neusatz), slovanský jazyk a slovanskou literaturu v singuláru, nikoli v plurálu, i když je zjevné, že v samotné publikaci píše o slovanských jazycích a literaturách, vycházeje z dobového stavu. Rozlišuje ještě např. severoslovanské jazyky, nemohl zachytit ani vrcholy ruského romantismu, natož „zlatý věk“ ruské literatury; jeho obraz slovanských literatur vrcholí spíše koncem 18. a počátkem 19. století, ale snaží se tím patrně vyhovět dobové ideologii, ale také zdůraznit reálnou, byt' relativní slovanskou kulturní jednotu (Šafařík 1826, 1963, 1983; Pospíšil 2004-2005, 2020b).

Frank Wollman (1888-1969) kdysi poukázal na to, že problém Slovanů je problémem slavismů, ale také antislavismů: jako by Slované jedním dechem produkovali věci společné, obecné, ale současně v duchu behaviorismu cíleně praktikovali anti- 
slavismy jako určitou oponenturu: možná právě to odlišuje slovanský jazykový, kulturní a historický celek od jiných celků, např. románského nebo germánského, totiž to, že národní a obecně slovanské rysy se staly ideologií, nabývajíce často subjektivního rázu.

Slovanská identita je tedy základem uvažování v tom smyslu, jak je prezentuje Valerij Vilinskij. Tato identita nepochybně existuje, ale je problematická, oslabuje i posiluje, dokonce se ztrácí nebo podléhá negaci; to vše třeba vzít v úvahu. Toto vše najdeme v díle Franka Wollmana, např. již v Slovesnosti Slovanů, kde se nejvíce přibližuje T. G. Masarykovi a E. Benešovi, že u Slovanů nachází schopnost přejímat, ale také syntetizovat a vyvíjet nové celky na hraně stávajících kulturních vrstev (viz citát dále).

Uvažování Valerije Vilinského vstupuje do světa v době narůstající světové krize hospodářské a politické v předvečer nové světové války. Odtud nárůst nového hledání a sjednocování, které mělo předcházet konfliktům, a slovanská otázka by mohla být takovým scelujícím faktorem, ale nakonec, jak vidno, nebyla; stejně jako před první světovou válkou to nebyla idea sociální, naopak sociálně orientované programy, socialistické a sociálnědemokratické, katastrofálně selhaly a probudily do života radikální síly, s nimiž se Vilinskij musel i ve svém spise vyrovnávat, tj. např. nové Rusko.

Do tohoto hledání patří v meziválečném Československu také úvahy o krizi demokracie, tj. právě tohoto proudu, který v slovanské otázce považuje Vilinskij - kromě katolického - za stěžejní.

Německá slavistka Anne Hultsch ve své fundamentální, komplexní knize o Valeriji Vilinském (Hultsch 2010) posuzuje jeho názor na křest’anský univerzalismus a slovanskou otázku kriticky. A doprovází ji přehlednou tabulkou, která ukazuje na složitou kombinovatelnost různých typologií Vilinského koncepce, jak jsem ji zjednodušeně vyložil výše, ale ani tato schémata a diagramy, přes svoji složitost a sofistikovanost, nevystihují Vilinského ,projekt“ v jeho celistvosti a diachronii. Je zřetelné, že tento koncept je synkretický nebo, chcete-li, hybridní. Zmiňuje se také o tom, že rusofilskou koncepci pokládá Vilinskij za připravenou k př̀konání „kritickým slavismem“ nebo, jak cituje Franka Wollmana, „vědeckým realismem“: „Methodologisch stellt Vilinskij der russophilen Konzeption ein konsequenzen, ein konkretes und streng wissenschaftliches, das nicht nur eine Diskussioner mögliche, sondern auch die Suche nach Wegenzur Korrektur und zur Erhellung des tatsächlichen Sachstandeseröffne [...] Zur Beurteilung der demokratischen und der russophilen Konzeption dient Vilinskij ihre Flexibilität und Praktikabilität als Hauptkriterium, dessen Tragbarkeit er an der russisch-polnisch-ukrainischen Frage näher untersucht" (Hultsch 2010: 315).

Zde se musíme zastavit: metodologická čistota je u Vilinského slabá; o to více je zde právě oné flexibility a praktičnosti; nicméně se ukazuje, že hlavní důraz kladený na problém rusko-polsko-ukrajinský a do jisté míry „uzávorkování“ (fenomenologicky „Einklammerung") nebo spíše taktika „laissez faire“ nebo „laissez passer“ nese s sebou značné problémy: jsou spojeny nepochybně s „měkkým podbřiškem Evropy“ (Balkánem), do něhož se nořily zájmy evropských mocností, německá osa Berlin - Bagdád, zájmy britské a ruské (tehdy; dnes i jiné) a tyto zájmy nejen nezmi- 
zely, ale spíše eskalovaly nyní a v různých modifikacích trvají dále, kdy k nim přistupuje problém albánský a postupující islamizace Evropy a světa (Štěpánek 2011, 2014, 2020). Zajímavé je, že preference osy rusko-polské s domnělým trianglem rusko-polsko-ukrajinským se objevuje např́klad i v koncepci slovanských literatur Jiřího Horáka (1884-1975), brněnského předchůdce FrankaWollmana na stolici slovanských literatur v rámci Slovanského semináře Masarykovy univerzity, manžela Slovenky Anny Gašparíkové (1896-1987), soukromé archivářky T. G. Masaryka, v letech 1945-1948 československého velvyslance v SSSR, později hlavně etnologa, profesora Univerzity Karlovy a ředitele Ústavu etnografie a folkloristiky Československé akademie věd (Horák 1948; Pospíšil 2012b) - na rozdíl od česko-jihoslovanské osy Wollmanovy.

Typologická sít' koncepcí, s nimiž Valerij Vilinskij pracuje, od základní dvojice „revoluční - státotvorná“ přes trojici „demokratická - katolická - rusofilská“ až k jejich charakteristice a rozpětí směrem k státu, Slovanstvu, Vatikánu, Evropě a světu, je nejen prŕlišs složitá a vykalkulovaná, ale přede vším neodpovídá reálné funkci tzv. slovanské otázky „,která je vlastním tématem jeho knihy. Ani demokratická, ani katolická koncepce totiž vlastně nepokládá tzv. slovanskou otázku za dominantní, za svou součást; spíše se s ní nějakým způsobem vyrovnává, zatímco tzv. rusofilská koncepce se sice výslovně týká slovanské otázky, ale přináší jen jedno z možných řešení. Zatímco tzv. demokratická a tzv. katolická koncepce se staví k slovanské otázce jako k něčemu vnějšímu, vnějškovému, rusofilská ji řeší jednostranně. To, k čemu Frank Wollman postupně dospíval ve svém díle, bylo hlavně uhájení slovanské otázky samostatně jako důležité součásti vnímání světa, která vycházela z objektivních i subjektivních faktorů (nikoli nadarmo byli lidé Wollmanovy a ještě dřívější generace oslněni romantickou „filozofií vưle“ v provedení A. Schopenhauera a F. Nietzscheho, byt' samozřejmě nesdíleli jejich pozdější nacionalistickou aplikaci) a směřovala především k regionální kreativitě, tj. k původnímu zpracování a transformaci vnějších i vnitřních podnětů, jak to uvádí ve své Slovesnosti Slovanů, jak jsme se toho dotkli v naší studii Sedmero poznámek k Wollmanově Slovesnosti Slovanů, která se v německé verzi stala součástí německého vydání knihy (Wollman 2003). Především jsou slavismy pro Wollmana autochtonní kvalitou a vlastností slovanského světa, něčím, co reálně existuje a spojuje různé slovanské projevy v celek slovanského světa. Podtrhuji také Wollmanovo trvání na existenci celku slovanských literatur oproti jejich znevažování. To je ona vědecká koncepce nebo vědecký realismus, na který se odvolává i Anne Hultsch, když srovnává Vilinského rozeklané pojetí s kontextem tohoto uvažování (Hultsch 2010). Wollmanovou metodou je vidění jevů ve vzájemných souvislostech a propojeních, nikoli izolovaně: to autor nejen deklaruje, ale také v praxi realizuje. Např́klad takto několika tahy načrtl problematiku středověkou, renesanční, humanistickou, reformační a rekatolizační: „Slovanský západ v XV. století odvracel se ve smyslu Ježíšovy ,blahověsti' od života, pro ,pravdu’ nešetřil života, bušil na samy brány zásvětí, popíral život. Zatím slunná Dalmácie, obluzována zeleno-modrým tajemstvím zlatoskvoucího Jadranu, vzdávala se hlasu života, o němž jí Jadran dával bezprostřední zprávy; první milenka, rafinovaná Itálie, stala se praeceptorkou in artibus. Duch středomořského člověka s krví, regenerovanou značnou příměsí barbarskou, vyspěl do té míry, že začal pochybovati o pravdivosti samospasitelného dogmatu římského. Ale albigenská krvavá lázeň učila přetvářce celou společnost a sv. inkvisice jednotlivce, nebyla-li tato dána už potřebou exaltace vášně a metafyziky, divokým hladem 
smyslů i fantasie: dualism pohanského života a křest’anské smrti stal se výrazem románského plemene. S tímto dualismem, jehož podstatou je lež, bila se husitská ,pravda’, tohoto Antikrista bičoval Chelčický i tě̌̌kopádný Luther, dobře vida, jak hluboko zasáhl sám kořen německé duše. Ještě smutný konec panteisty Giordana Bruna dokázal, že Roma po dvou stoletích trestala stejně jako za Husa neshodu s dogmatem. Ovidius, básník Amorů, měl vlastně býti průvodcem Dantovým, prrišed k němu z Provence, a nikoli ,křest'anský' Vergilius. Panna Maria - Beatrice byl vítězící hlas lásky a života. Z prachu klášterních knihoven zvedala se antika jako zapadlý sen; ale málokdo ji chápal v její pravdivé prostotě a síle: snad Petrarca domyslil, když snil o starém imperiu rrímském a v křest'anské Praze snažil se čarovným snem svésti svůj gotický protějšek, císaře Karla, jemuž slovanská krev matky položila v ústa slovo ,humanitas' tam, kde se jednalo o sedláka. Ale nízká pokřivenost typu Borgia, jenž nastoupil místo typu perikleovského, alexandrovského a caesarského, tak vzdálená ještě samému typu Macchiaveliho, dokazuje, že daleko bylo do pravé a pravdivé obrody smyslů, srdce a ducha. Není divu, že z renesance po velkých nábězích italských zůstal v slovesném umění jen odvar - literární humanism, který se zcela neškodně mohl spojovati s katolicismem i s reformací a přes Polsko dokonce s pravoslavím. Ale i tento teoretický humanismus, jenž z rrímské vzdělanosti přejal vlastně plně jen vadu, privilegovaně třídní výlučnost, stupňovanou smrtí jazyka, kdysi tak slavného, a kontrastující tolik s davovou obecností hnutí reformačního, byl umělecky i ideově postupem, třeba zůstal - daleko přes své jméno -od ,humanity’ Karlovy a humanity moderní“ (Wollman 1928: 36-37).

Poněkud blíže rusofilskému, tedy emotivnějšímu, ale hlavně jazykově, kulturně a mentálně orientovanému pojetí je český slavista, slovakista a rusista Josef Jirásek (18841972), zejména ve vztahových česko-ruských studiích (Jirásek 1922, 1933, 1945, 1946; Franta, Pospísil 2009). Základní Wollmanovou tezí je to, že slovanské literatury vznikaly na evropských kulturních křižovatkách jako produkt mediteránního kulturního typu: právě zde Wollman anticipoval podobné snahy Dionýze Ďurišina a italských komparatistů (Pospíšil 2000b, 2013). Nehledě na složité historické osudy jednotlivých slovanských pospolitostí (tatarský vpád u východních Slovanů, turecké války u jižních, germanizační tlak u západních) vidí Wollman kontinuitu slovanskou a evropskou, nebot’ nebylo možno zabránit průniku a proudění literárních látek: navíc se Slované neuzavírali ani prouděním východním (Byzanc a Asie). Z tohoto hlediska mohl Wollman konstatovat, že „slovanské literatury byly bohatší než literární průměr západoevropský o vlastní hodnoty“ (Wollman 1928: 234), že sdílely stejné nebo podobné hodnoty, takže „na literární mapě Evropy slovanské oblasti byly by zakresleny asi týmiž anthropologickými barvami a týmiž zónami historických epoch a myšlenkových proudů; jen snad by byl rozdíl v stupni barev a v síle pruhů. Ale kromě toho přistupovaly by mezislovanské odstíny barevné a daleko složitější sít' vlivů mezislovanských, zvláště v oboru látkovědy a také $\mathrm{v}$ typologii. Toto mezislovanské plus není způsobeno jen dědictvím byzantské kultury a orthodoxií, není jen podmíněno více méně organickým zasahováním západoevropských vlivů, leč též jejich přijetím, výběrem a způsobem zpracování.“ (Wollman 1928: 233-234). Je to přesnější a reálnější než př́liš teoretické a spekulativní uvažování o tzv. slovanské pozice a hledání jejího př́íliš jednostranného uchopení v linii tzv. demokratické, katolické nebo rusofilské.

Josef Jirásek byl badatel, který šel ad fontes, byl sečtělý, dokázal spojovat často zdánlivě nespojité a protilehlé problematiky. Jiráskova tvorba má specifické postavení po známých dílech a syntetizujících snahách ve sfére česko-ruské např. u Josefa 
Dobrovského, Josefa Jungmanna, Pavla Jozefa Šafárika/Šafaříka, Karla Jaromíra Erbena, Václava Hanky aj. Jirásek charakterem svého díla stojí na pomezí vědeckého a vědecko-populárního bádání, často využívá žánru přehledové stati, komplexní studie, eseje, kompilace a populární syntézy. Z metodologického hlediska se Josef Jirásek jako eklektik v dobrém slova smyslu pohybuje mezi pozitivismem s jeho akribií a úctou k materiálu (Stoffgeschichte), duchovědou a ideografií (Geistesgeschichte, Ideengeschichte) a specifickou psychologickou a narativní orientací. Tím se blíží jiným brněnským slavistům, zejména Aloisi Augustinu Vrzalovi (1864-1930, Pospíšil 1991a, 1991b, 1992a, 1992b, 1993a, 1993b, 1996a, 1996b) a otci Valerije Vilinského Sergijovi (1876-1950).

Jirásek je především vypravěčem literárněhistorických příběhů a populárněvědeckých syžetů. Z tohoto zorného úhlu nutno také chápat značnou popularitu jeho Přehledných dějin ruské literatury, která se znovu oživila v 60. a 70. letech 20. století (Jirásek 1945, 1946). Právě tato kniha sehrála důležitou úlohu při formování českých představ o ruské literatuře v druhé polovině 20. století i v pohledu na slovanskou otázku ve smyslu kritickém, ale také mírně rusofilském. Je zřejmé, že Jirásek přitom vychází z předcházejících koncepcí českého národního obrození (Jirásek 1945, 1946). I zde sem silně zasahuje české vidění Ruska a ruské literatury, takže mohou vzniknout námitky, že je tu méně literatury jako estetického artefaktu a více různých společenských a politických okolností jejího vzniku a vývoje. V tom právě spočívá už zmíněný Jiráskův eklekticismus. Jiráskovi je blízký širší kulturní okruh v duchu kulturně historické školy 19. století, německé Ideengeschichte či Geistesgeschichte. To by už tehdy vypadalo poněkud archaicky, kdyby se to svou povahou a důkladnou geopolitickou a historickou znalostí Jiráskovou nepodobalo spíše dnešním areálovým, resp. filologicko-areálovým studiím vycházejícím z filologie, ale transcendujícím dál k sociologii a psychologii literárního umění - ani zde nechybějí imanentní př́stupy, ale jen v omezené míře. Jiráskův přehled je silně zasažen prostorovým viděním literatury: již grafické označení Ruska na brožované obálce jako Moskva, Petrohrad či Sankt-Petěrburg a potom téma revoluce a nakonec rudá hvězda ukazuje na důležitost, již Jirásek přikládal politické a sociální symbolice jednotlivých období, resp. jakou důležitost přikládal kulturně politickým epochám a vývoji státu v dějinách literatury, resp. národní literatury.

Slovanská otázka, v podstatě specifikum etnicko-jazykové a kulturně historické se u západních Slovanů často prolíná s areálovým hlediskem, v tomto případě se střední Evropou, stejně jako u jižních s otázkou balkánskou a u východních Slovanů s problémem ugrofinským a turkotatarským (turkickým), byt' poněkud jinak a v jiné síle. To se projevuje $\mathrm{i} v$ různé recepci cizích jevů, jež jsou v různých slovanských prostredích různě recipovány. Takto jsem například líčil jiné vnímání proslulého díla Oswalda Spenglera v ruském a českém prostředí, kde vstupuje do jiných historicko-ideologických souvislostí národních i kontextově a dobově politických, zejména od 30. let 20. století, kdy se někteř́i filozofové a kulturní historikové zamýšlejí nad problémy demokracie související právě s oním demokratickým pojetím slovanské otázky u V. Vilinského (Pospíšil 2020a). Takto vnímá kritiku demokracie v předvečer druhé světové války např. český filozof J. L. Fischer (Fischer 1933a, 1933b,1990, 2005). Konsekvencemi může být i hledání jiného modelu společenského uspořádání a jiných fillozofických východisek, která se vracejí k mi- 
nulým formacím nebo ke krajním myšlenkovým polohám (Borský 1912, 1935; Palkovský 1936). Kdybychom šli ještě dále do minulosti, zjistili bychom, že „slabosti“ tzv. demokracie, kterou ovšem každý chápe trochu jinak a která se také jinak realizuje $\mathrm{v}$ různých dobách a $\mathrm{v}$ různých společenstvích národních a geopolitických (jiná je demokracie v USA, jiná ve Velké Británii, jiná v Německu, jiná je ,ř́zená“ demokracie v rámci prezidentského systému např. v Ruské federaci, Francii nebo Polsku, jiná v parlamentním systému u nás, nebo v členské zemi NATO Turecku, kde směřuje k vytváření syntézy mezi sekulárním a teokratickým státem apod., ačkoli tu jistě najdeme společné, hlavně formální rysy), nemusejí vyplývat jen z vývoje a výskytu jiných ekonomických a politických situací, jako tomu bylo ve 30 . letech 20. století, ale tkví také v obnovených polohách tohoto systému, jak se v dějinách různě realizovaly. $\mathrm{V}$ tomto smyslu nelze neodkázat na koncepce Alexise de Tocquevilla v díle $O$ demokracii v Americe (Tocqueville 1. díl 1835, necelé dva roky před Puškinovou smrtí) a v jeho variantě v proslulé Puškinově recenzi na Paměti Johna Tannera (de Tocqueville 2000; Пушкин 1975-1976; Pospíšil 1973, 1986, 1999; Shaw 1966; Boden 1968) ${ }^{1}$ : každá však kritizovala demokracii z jiného zorného úhlu, ale současně oba postihli některé její obecné rysy, které přerůstají tehdejší podobu americké demokracie.

Hledání Valerije Vilinského v okruhu tzv. slovanské otázky vstupuje do širokých souvislostí mezinárodních i ryze českých: v ruském myšlení jde především o euroasijství, které tvoř́ zvláštní myšlenkový okruh, který má své kořeny a pokračování, koneckonců i v ruské ideologii a politice a souvisí právě s ruskou emigrací v meziválečném Československu. Vilinského vztah k eurasijství a jeho stoupencům a kritikům je ovšem zcela samostatným tématem, které překračuje hranice této reflexe.

\section{Použitá literatura}

Balmont, Konstantin. Duše českých zemí ve slovech a činech. Básnické eseje a překlady. Vydání, překlad, studie, komentáře Danuše Kšicová. Brno: Masarykova univerzita, 2001.

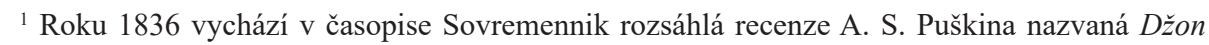
Tenner (John Tanner). Představuje kritický komentář knihy, kterou vydal roku 1830 v New Yorku Edwin James, znalec života severoamerických Indiánů. Jde o Jamesův záznam a adaptaci originálního vyprávění Johna Tannera, muže, který prakticky celý život prožil mezi algonkinskými Indiány (původně žijícími na území od Atlantského oceánu k Velkým jezerům). Jako dítě jižanského osadníka byl Indiány unesen, držen dlouhá léta jako zajatec, pak naturalizován a zcela integrován do indiánského společenství. E. James ličći Johna Tannera jako padesátiletého muže, mohutné tělesné stavby, rychlých reakcí a nekompromisnosti, jíž uchvacoval i Indiány [V indiánském zajetí. Život a př́běhy Johna Tannera. Orbis, Praha 1956, přel. Josef Cincibus. Kniha byla vydána v krásné grafické úpravě, s mapou a etnograficko-lingvistickými vysvětlivkami. Překlad byl bohužel pořízen z druhého amerického vydání (San Francisco 1940), v němž chybějí poznámky E. Jamese, jeho předmluva a př́loha. Tyto byly přeloženy z německého textu (Weimar 1953, přel. Eva Lipsová). V době, když jsem koncipoval svou studii pro tehdejší časopis Československá rusistika v roce 1986, opírali jsme se primárně o originální první vydání, (které nám bylo dostupné ve formě fotokopie, pořízené na univerzitě v Ann Arbor v Michiganu) Narrative of the Captivity and Adventures of John Tanner during Thirty Years Residence among the Indians in the Interior of North America. Prepared for the Press by Edwin James, M. D., New York: G. and C. H. Carvill, 108 Broadway, 1830. 
Boden, Dieter. Das Amerikabild im russischen Schrifttum bis zum Ende des 19. Jahrhunderts. Hamburg: De Gruyter Verlag, 1968.

Borský, Lev. Bedřich Nietzsche. Vývoj jeho filosofie. Praha: Naklad „Dr. Ant. Hajna“, 1912.

Borský, Lev. Vůdcové lidstva a jeho svůdci. Základy biopolitiky. Edice Cesta, Praha: Naklad „Otakar Skýpala“, 1935.

Fischer, Josef Ludvík. Krise demokracie. Kniha druhá. Řád. Brno: Pokrokový obzor, Index, 1933a.

Fischer, Josef Ludvík. Krise demokracie. Kniha prvá. Brno: Svoboda, Pokrokový obzor, Index, $1933 \mathrm{~b}$.

Fischer, Josef Ludvík. Osobnost, dílo, myšlenky. Olomouc, 1990.

Fischer, Josef Ludvík. Krise demokracie. Praha: Karolinum, 2005.

Franta, Vladimír, Ivo Pospíšil. Josef Jirásek jako rusista, slovakista a umělec slova. Brno: TRIBUN EU, 2009.

Hantos, Elemér. Das Geldproblem in Mitteleuropa. Jena, 1925a.

Hantos, Elemér. Die Handelspolitik in Mitteleuropa. Jena, 1925b.

Hantos, Elemér. Die Kulturpolitik in Mitteleuropa. Stuttgart, 1926.

Hantos, Elemér. Das Donauproblem. Wien, 1928.

Hantos, Elemér. Mitteleuropäische Eisenbahnpolitik. Zusammenschluß der Eisenbahnsysteme von Deutschland, Österreich, Ungarn, Tschechoslowakei, Polen, Rumänien und Jugoslawien. Wien, 1929.

Hantos, Elemér. Das mitteleuropäische Agrarproblem und seine Lösung. Berlin, 1931a.

Hantos, Elemér. Mitteleuropäische Kartelle im Dienste des industriellen Zusammenschlusses. Berlin, 1931b.

Hantos, Elemér. L' Europe centrale. Une nouvelle organisation économique. Paris, 1932a.

Hantos, Elemér. Mitteleuropäische Wasserstraßenpolitik. Berlin, 1932 b.

Horák, Jiří. Z dějin literatur slovanských. Stati a rozpravy. Uspořádal Julius Dolanský a Jan Thon. Praha: Jos. R. Vilímek, 1948.

Horyna, Břetislav. Dějiny rané romantiky. Fichte, Schlegel, Novalis. Praha: Vyšehrad, 2005.

Hultsch, Anne. Ein Russe in der Tschechoslowakei. Lebenund Werk des Publizisten Valerij S. Vilinskij (1903-1955). Köln: Böhlau, 2010.

Jeřábek, Miroslav. Za silnou střední Evropu. Středoevropské hnutí mezi Budapeští, Vídní a Brnem v letech 1925-1939. Praha: Dokořán, 2008.

Jirásek, Josef. Slovensko: jeho dejiny, pomery zemepisné a hospodárske, jazykové, literárne a kultúrno-politické. Malý sprievodca po Slovensku. Bratislava, 1922.

Jirásek, Josef. Češi, Slováci a Rusko: studie vzájemných vztahů československo-ruských od r. 1867 do počátku světové války. Praha: Vesmír, 1933.

Jirásek, Josef. Přehledné dějiny literatury ruské. Brno-Praha: Josef Stejskal Miroslav Stejskal, 1945.

Jirásek, Josef. Rusko a my: dějiny vztahů československo-ruských od nejstarších dob do roku 1914. Praha - Brno: Miroslav Stejskal a Josef Stejskal, 1946.

Lappo-Danilevskij, Aleksandr. „Politische Ideen in Rußland des 18. Jahrhunderts.“ Bausteine zur slavischen Philologie und Kulturgeschichte, Neue Folge 1. Köln Weimar - Wien: BöhlauVerlag, 2005.

Palkovský, Břetislav. Za sovětskou civilizací. Praha: Orbis, 1936.

Pospíšil, Ivo. „Dynamika rusko-amerických literárních vztahů od počátku do konce 19. 
století.“ Universitas 5, 1973: 28-35.

Pospíšil, Ivo. „Puškinův John Tanner - jeho kontext, smysl a funkce“. Čs. rusistika 3, 1986: 106-111.

Pospíšil, Ivo. „Alois Augustin Vrzal podruhé“. Lidová demokracie 10.12.1991a: 5.

Pospíšil, Ivo. „Alois Augustin Vrzal“. Lidová demokracie 1.11.1991b: 5.

Pospíšil, Ivo. „Alois Augustin Vrzal a jeho duchovní dědictví“. Universitas 6, 1992a: 27-30.

Pospíšil, Ivo. „Alois Augustin Vrzal: A Catholic Vision of Slavonic Literatures“. Slovak Review 2, 1992b: 166-171.

Pospíšil, Ivo. „Alois Augustin Vrzal: Koncepce a dokumenty“. SPFFBU D 40, 1993a: 53-62.

Pospíšil, Ivo. Srdce literatury. Alois Augustin Vrzal (1867-1930). Brno: Albert, 1993b.

Pospíšil, Ivo, Zelenka, Miloš. René Wellek a meziválečné Československo. Ke kořenům strukturální estetiky. Brno: Masarykova univerzita, 1996a.

Pospíšil, Ivo. „Sergij Vilinskij an der Masaryk-Universität in Brünn: Fakten und Zusammenhänge“. Wiener Slavistisches Jahrbuch 42, 1996b: 223-230.

Pospíšil, Ivo. Krize univerzit a literární vědy na sklonku tisíciletí a slavistika. [V:] Hana Gladkova, Vladimír Kř́žz (eds.) Slavica Pragensia ad tempora nostra. Konference ke 150. výročí založení stolice slovanské filologie na Karlově univerzitě. Praha: Univerzita Karlova, Euroslavica, 1998, 267-271.

Pospíšil, Ivo. Na výspě Evropy (Skici a meditace ke 200. výročí narození Alexandra Sergejeviče Puškina). Brno: Masarykova univerzita, 1999.

Pospíšil, Ivo. „Dva moravští slavisté: Alois Augustin Vrzal a Sergij Grigorovič Vilinskij“. Slavia Occidentalis 57, 2000a: 219-233.

Pospíšil, Ivo. Il Mediterraneo. Una rete interletteraria. La Méditerranée. Un réseau inter littéraire. Stredomorie medzi literárnasiet'. A cura di Dionýz Ďurišin e Armando Gnisci. Roma: Università degli studi di Roma „La Sapienza“, Studi (e testi) italiani. Collana del Dipartimento di italianistica e spettacolo, Bulzoni Editore, 2000b.

Pospíšil, Ivo (ed.). Litteraria Humanitas XI. Crossroads of Cultures: Central Europe Kreuzwege der Kulturen: Mitteleuropa Křižovatky kultury: Střední Evropa. Brno: Masarykova univerzita, 2002.

Pospíšil, Ivo. „Pavel Josef Šafárik jako slavista.“ Košice: Universitas S̆afarikiana XXXIV/7-8, 2004-2005: 3-4,

Pospíšil, Ivo. „Problémy literární evoluce a slovanské literatury“. SPFFBU, Bohemica Litteraria V/8, 2005, 91-101.

Pospíšil, Ivo. Střední Evropa a Slované (Problémy a osobnosti). Brno: Ústav slavistiky Filozofické fakulty Masarykovy univerzity, 2006a.

Pospíšil, Ivo. „Slavismy a antislavismy za jara národů Franka Wollmana: analýzy a přesahy“. [V:] Hana Hlôšková, Anna Zelenková (red.) Slavista Frank Wollman v kontexte literatúry a folklóru. Bratislava - Brno: Ústav etnológie SAV, Slavistická společnost Franka Wollmana v Brne, Česká asociace slavistů, Slavistický ústav Jána Stanislava SAV, 2006b, 103-112.

Pospíšil, Ivo. „Potřebná edice o ruském myšlení. (Aleksandr Lappo-Danilevskij, Politische Ideen in Rußland des 18. Jahrhunderts. История политических идей в России в XVIII веке в связи с общим ходом развития культуры и политики. [Istoriiā politicheskikh ideř v Rossii v KhVIII veke v sviâzi s obshchim khodom razvitiiâ kul'tury i politiki].) Bausteine zur slavischen Philologie und Kulturgeschichte, Neue Folge 1. Böhlau Verlag, 
Köln - Weimar - Wien 2005). Slavica Litteraria X/9, 2006c: 326-327.

Pospíšil, Ivo. „Jiří Horák a obrysy jeho koncepce srovnávacích slovanských literatur“. [V:] Hana Hlôšková, Ivo Pospíšil, Anna Zelenková (eds.) Slavista Jiř́i Horák v kontexte literatúry a folklóru I-II. Brno: Česká asociace slavistů, Katedra etnológie a kultúrnej antropologie FiF UK Bratislava, Slavistická společnost Franka Wollmana v Brně, TRIBUN EU, 2012b, 67-77.

Pospíšil, Ivo. Central Europe: Substance and Concepts. Nitra: Constantine the Philosopher University, Faculty of Central European Studies, 2015a.

Pospíšil, Ivo. „Франк Вольман и его полемики о панславизме“. [Frank Vol'man i ego polemiki o panslavizme]. [V:] Zofia Chyra-Rolicz, Tomasz Rokosz (red.) Panslawizm wczoraj, dziś, jutro. Siedlce: Uniwersytet Przyrodniczo-Humanistyczny w Siedlcach, Wydział Humanistyczny, Instytut Nauk Społecznych i Bezpieczeństwa, Instytut Filologii Polskiej i Lingvistyki Stosowanej, Instytut Historii i Stosunków Międzynarodowych, 2016, 147-160.

Pospíšil, Ivo. „Slovanský svět existuje: rozpad, negace, revival aneb hledání slovanské identity“. Slavica litteraria 2, 2016: 13-32.

Pospíšil, Ivo. „Rodina Vilinských v Československu: Valerij Vilinskij k některým jevưm české literatury“. Slavica Litteraria 2, 2017a: 39-47.

Pospíšil, Ivo. Ruský emigrant sedívá na meziválečné Československo a česko-slovenský vztah. [V:] Ivo Pospíšil (red.) Český a slovenský kulturní a politický prostor (vzájemnost - nevzájemnost, vstřícnost - rezistence, ústup - expanze). Česká asociace slavistů. Brno: Jan Sojnek, Galium, 2017b, 151-161.

Pospíśil, Ivo. "The Secular, the Sacral, and the Three Stages of the Postsecular in Russian Literature: The Past and the Present". [In:] Danuta Sosnowska, Ewelina Drzewiecka (eds.) The Experience of Faith in Slavic Cultures and Literatures in the Context of Postsecular Thought. Warszawa: Wydawnictwo Uniwersytetu Warszawskiego, 2018, $178-188$.

Pospíšil, Ivo. „Освальд Шпенглер и чешский контекст (маргинальные заметки)“. [Osval'd Shpengler i cheshskiü kontekst (marginal'nye zametki)]. [V:] Роман Мних, Оксана Блашкив (ред.) Освальд Шпенглер и славяне. [Roman Mnikh, Oksana Blashkiv (red.) Osval'd Shpengler i slaviâne.]. Opuscula Slavica Sedlciensia, tom XIII, IKRiBL, Stowarzyszenieim. Franciszka Karpińskiego, 2020a, 122-151.

Pospíšil, Ivo. „П. Й. Шафарик, А. Мицкевич и концепция русской литературы: у колыбели литературоведческой славистики“. [Mitskevich i kontseptsiia russkoй literatury: u kolybeli literaturovedcheskoî slavistiki]. [V.:] Magdalena Dąbrowska, Piotr Głuszkowski, Zbigniew Każmierczyk (red.) Адам Мицкевич и славяне. [Adam Mitskevich i slaviāne]. Warszawa: Wydawnictwo Naukowe Scholar, 2020b, 210-220. Pospíšil Ivo, Michael Moser (eds.). Comparative Cultural Studies in Central Europe. Brno: Ústav slavistiky Filozofické fakulty Masarykovy univerzity, 2004.

Shaw, Thomas J. „Puškin on America: His 'John Tanner' “ [In:] Orbis scriptus. München: Wilhelm Fink Verlag, 1966, 739-756.

Schaffarik, Paul Joseph. Geschichte der slawischen Sprache und Literatur nach allen Mundarten. Buda: Ofen, Mit kön. ung. Universitäts-Schriften, 1826.

Šafárik, Pavel Jozef. Dejiny slovanského jazyka a literatury vrtkých nárečí. Bratislava: Vydavatel'stvo SAV, 1963.

Šafárik, Pavel Jozef. Geschichte der slawischen Spracheund Literatur nach allen Mundarten. Fotomechanischer Neudruck mit einem Vorwort von Prof. Dr. Jan Petr, 
CSc., Prag. Bautzen: VEB Domowina-Verlag, 1983.

Štěpánek, Václav. Jugoslávie - Srbsko - Kosovo. Kosovská otázka ve 20. století. Brno: Masarykova univerzita, 2011.

Štěpánek, Václav. Východní otázka: od počátků do konce 60. let 19. století. Brno: Masarykova univerzita, 2014.

Štěpánek, Václav. Východní otázka II. Od Velké východní krize do počátku 20. století. Brno: Masarykova univerzita, 2020.

Tocqueville de, Alexis: Demokracie v Americe. Praha: Academia, 2000.

Vilinskij, Valerij S. K slovanské otázce. Tři koncepce slovanské vzájemnosti. Praha: Václav Petr, 1930.

Wollman, Frank. Slovesnost Slovanů. Praha: Vesmír, 1928.

Wollman, Frank. K methodologii srovnávací slovesnosti slovanské. Brno: Filosofická fakulta Masarykovy university, 1936.

Wollman, Frank. Zu vergleichenden slavischen Literaturwissenschaft. Prag: Selbstverlag, 1937.

Wollman, Frank. Slovanství v jazykově literárním obrození u Slovanů Praha: SPN, 1958. Wollman, Frank. Slavismy a antislavismy za jara národů. Praha: Academia, 1968.

Wollman, Frank. Die Literatur der Slawen. Herausgegeben von Reinhard Iblerund Ivo Pospíšil. Renate Belentschikow, Reinhard Ibler (Her.). Bd. 7. Frankfurt am Main Berlin - Bern - Bruxelles - New York - Oxford - Wien: Peter Lang, 2003.

Wollman, Frank. „Slovesnost Slovanů.“ [V.]: Ivo Pospíšil, Miloš Zelenka, Eva Niklesová (red.), Česká asociace slavistů ve spolupráci s Ústavem slavistiky Filozofické fakulty Masarykovy univerzity, Středoevropským centrem slovanských studií a Slavistickou společností Franka Wollmana, 2. vyd. Brno: TRIBUN EU, 2012.

Wollman, Slavomír. Porovnávacia metóda v literárnej vede. Bratislava: Tatran, 1988.

Wollman, Slavomír. Česká škola literární komparatistiky. Praha: Univerzita Karlova, 1989.

Wollman, Slavomír. Slovanské literatury ve střední Evropě. Brno: Masarykova univerzita, 2013.

Бальмонт Константин. Душа Чехии в слове и деле. Поэтические оценки и образцы. Capbreton, 1931.

[Bal'mont Konstantin. Dusha Chekhii v slove i dele. Poèticheskie otşenki i obraztŝy. Capbreton, 1931]

Поспишил, Иво. „Архитектоника пространства и времени (Общие места в поэтике очерков К. Д. Бальмонта Где мой дом)“ [В:] Н. П. Кубарева (ред.) К. Бальмонт и мировая литература. Сборник научных статей Международной конференици (2-4 октября 1994 г.). Шуя 1994, 14-21.

Поспишил, Иво. „Изменение темы и метода - Сергий Вилинский в Университете им. Масарика“. Русский язык как инославянский IV, 2012a: 7-19.

[Pospíšil, Ivo. Izmenenie temy i metoda - Sergiǐ Vilinskiī v Universitete im. Masarika.

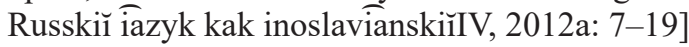

Поспишил, Иво. „Научная судьба Сергия Вилинского: самореализация ученого-эмигранта в чужой среде“. Питання літературознавства 92, 2015b: 35-46.

[Pospíšil, Ivo. Nauchnaia sud'ba Sergîa Vilinskogo: samorealizatsiia uchenogo-èmigranta v chuzhoĭ srede]. Pytannia literaturoznavstva 92, 2015b: 35-46]

Пушкин, Александр. Собрание сочинений в 10 томах. Т.5-7. Москва, 1975-1976.

[Puškin, Alexander, Sobranie sochineniı̌ v 10 tomakh. T. 5-7. Moskva:1975-1976] 
Иво Поспишил

\section{ВАЛЕРИЈ ВИЛИНСКИ И СЛОВЕНСКО ПИТАҢЕ, ЊЕГОВ КОНТЕКСТ И КРИЗА ТРИДЕСЕТИХ ГОДИНА 20. ВЕКА}

\section{Резиме}

Руски правник, политиколог, новинар, књижевни критичар, историчар Валериј Вилински (1903-1955) био је несумњиво човек трагичне судбине. Син контрактуалног професора Масариковог универзитета Сергеја Вилинског (1876-1950), након емиграције из Одесе, где је овај руски медиевиста, а у једном краћем периоду и учитељ Михаила Бахтина, био проректор Новоруског универзитета, боравио је у Бугарској (где је радио у руским гимназијама, али и као банкарски службеник), а одиграо је важну улогу и у политичком развоју Чехословачке после 1945 . У међуратном периоду, током протектората, као и у послератном периоду написао је десетине књига, стотине студија и мањих чланака на чешком, руском, словачком, пољском и другим језицима (темељну студију о њему написала је немачка слависткиња Ана Хулч). У својим радовима бавио се питањима руске револуције, развојем хришћанства и хришћанског унијатства, католичанства и католичком књижевношћу, био је познавалац чешко-словачких односа и чешке књижевности католичке оријентације.

Тему овог рада, чији се аутор више пута бавио обојицом Вилинских - оцем и сином, чини минуциозна студија Валерија Вилинског О словенском питағу. Три концепиије словенске узајамности (1930). Вилински овде представља три концепције тзв. словенске узајамности: демократску, католичку и русофилску.

У овом чланку критички се проматра рад Валерија Вилинског у позадини опште кризе тридесетих година 20. века и тумачи повезаност наведених концепција са другим појавама међуратне Чехословачке, где је Вилински живео. Истраживање се надовезује на њему слична у стручној литератури. Контекст анализе гради неколико личности које су се у наведеном периоду бавиле сличним питањима: слависта и компаратиста Франк Волман, слависта, русиста и словакиста и Јосеф Јирасек, Бретислав Палковски, Лав Борски, Ј. Л. Фишер и други. Концепције словенске узајамности којима се бавио Валериј Вилински код њих изгледају унеколико сложеније, мање су схематске и више одговарају реалности међуратног периода са његовом кризом демократије и тражењем нових политичких концепата.

Кључне речи: Валериј Вилински, словенско питање, три концепције словенске узајамности, општа криза тридесетих година 20. века. 